\title{
Role of Total Quality Management on Entrepreneurial Orientation and SMEs Export Execution
}

\author{
Cross Ogohi Daniel ${ }^{1 *}$ and Mohammed Rabiu Musa ${ }^{2}$ \\ ${ }^{1}$ Department of Public administration/Banking \& Finance \\ Nile University of Nigeria, Abuja, Nigeria \\ ${ }^{2}$ Department of Business Administration \\ Nile University of Nigeria, Abuja, Nigeria \\ ${ }^{*}$ Corresponding author's email: Drdancrossogohi1980 [AT] gmail.com
}

\begin{abstract}
The reason for this examination was to explore the interceding job of Total Quality Management (TQM) between entrepreneurial orientation (EO) AND SME trade executions in the assembling area. This investigation was begun from the way that lone a couple of studies have inspected on how the company's impalpable assets and capacities, for example, EO and TQM drives Small and Medium Enterprise's' export execution. A few questionnaires in Likert scale were utilized to gather the information and 364 usable reactions were gotten from the owner/CEO of exporting SMEs. Incomplete Least Squares Structural Equation Modeling (PLS-SEM) was utilized for the information examination. The discoveries uncover noteworthy connection among Entrepreneurial Orientation and TQM with Small and Medium Enterprise export execution. Besides, this investigation found the correlative interceding job of TQM among Entrepreneurial Orientation and SME export execution of production sector. This investigation has suggestions for proprietor/supervisors of SMEs. The outcomes offer a superior comprehension with respect to EO and TQM usage to SMEs proprietor/chiefs. In this way, proprietor/directors of SMEs can take better choices for the execution of TQM rehearses. Moreover, as far as researcher could possibly know, this investigation looks at SMEs export execution in relationship with the TQM as the moderating variable between EO and SME export execution.
\end{abstract}

Keywords---- Entrepreneurial Orientation, Total Quality Management, Export execution, Small and Medium-Sized Enterprise

\section{INTRODUCTION}

Export assumes a significant job in nation's economy, impacting the degree of monetary development, business and the parity of installments (Ahmad et al., 2017; Fatemah and Qayyum, 2018). The assembling part is assuming a significant job in export improvement. The export of assembling area has been in low level throughout the previous not many years (Economics, 2016). As per the report of Commerce and Industry, manufacturing area development has diminished from 5.7 percent to 6.0 percent, which has likewise influenced the presentation of export-oriented manufacturing sub-sectors, for example, sports goods, surgical, apparel, cutlery and furniture industry. Since numerous SMEs are working in these parts, thus this declining execution of assembling additionally influenced the SMEs export execution. Decreasing in export causes exchange deficiency and the inability to satisfy exchange quantity has become a weight on the economy (Baffa, 2016; Dan, 2016).

The organizations of assembling segment are looking for new ways to build the worth and the nature of their items, which can expand the exports of manufacturing part. By and large, producing SMEs current business situation is feeling the squeeze because of progressively complex market and changing client inclinations. Subsequently, producing SMEs has gotten wide consideration for the extent of further research by a few creators and specialists (Mishra, 2016). Additionally, Entrepreneurial Orientation (EO) and its effect on firm export execution have gotten considerable consideration in export setting (Chen et al., 2016). In light of the adjustments in the business condition because of dynamic nature of export showcase, EO is increasing more significance because of critical impact on firm export execution and giving the supportable upper hand. EO can change the creation procedure, receiving advancement rehearses and new outlet for items, and so on (Zehir et al., 2015). Essentially, EO should prompt firms' higher export execution and SMEs with solid EO will clearly perform better (Sahoo and Yadav, 2017). Nonetheless, the effective usage of EO relies upon director's information, disposition, duty and experience (Wiklund and Shepherd, 2003). There are numerous examinations that revealed the significance and non-significance consequences for SME export execution (Feder, 2015; Frishammar and Andersson, 
2009). At this point, the problem of poor SME export execution through EO is because of the absence of different systems and application.

The present research direction is that, while entrepreneurial orientation decides explicit key choices and asset designation for the association (Wiklund and Shepherd, 2005), successful operationalization of EO requires arrangement with operational setting (Gupta and Batra, 2015). For instance, firm enterprising vision, capacities and exercises alone won't be sufficient to make progress, except if there is TQM reasoning in the association (Sahoo and Yadav, 2017). Besides, the idea of TQM is getting the consideration of assembling SMEs step by step. The assembling, SMEs should utilize the best method to improve the client's certainty at all time locating a Quality Management System (Pearson, 2015).

Thus, TQM can help SMEs business people and chiefs deal with their activities and creation effectiveness and keep up the top class producing framework (Konecny and Thun, 2011). SMEs contrasted and enormous firms are exceptionally delayed to embrace the TQM rehearses because of high cost and operational expense (Pearson, 2015). In regard to Nigeria SMEs setting, the board needs more aptitude and hierarchical capacities which can infer poor procedures arranging and HR the executives bringing about hesitance for receiving TQM (Ajiya et al., 2017). In any case, SMEs without compelling TQM framework is relied upon to be increasingly successful (Lages et al., 2009). Accordingly, right now business condition, execution of the best TQM rehearses and moving the EO into doable key exercises to satisfy the company's goals is fundamental.

Past examinations gave little consideration to the backhanded impact of TQM among entrepreneurial orientation and small and medium enterprise export execution relationship in the assembling area of Nigeria. In this manner, it is progressively reasonable to have a superior under-remaining of the circuitous impact of TQM influencing on entrepreneurial orientation- small and medium enterprise export execution relationship. Thusly, the present examination researches the intervening job of TQM among EO and SME export execution with regards to Nigeria.

\section{LITERATURE REVIEW}

SMEs are characterized in both created and creating nations dependent on various factors, for example, area, size, age, number of representatives, resource worth and deals turnover (Rahman, 2001). The Nigerian assembling SMEs characterized it dependent on the quantity of representatives and the yearly deals turnover and dependent on that those endeavors whose yearly deal turnover are not in excess of 250 fifty million Naira with less than 200 fifty workers are called SMEs (SMEDAN, 2016). The Nigerian SMEs contribute $78 \%$ to the non-urban work power, $30 \%$ in GDP, and $25 \%$ in export procuring, individually (Dar et al., 2017).

Nonetheless, in the present exceptionally serious business condition, SMEs are looking for systems to improve their exhibition explicitly as far as export commitment. Pioneering direction (EO) is an administrative capacity which firms leave about innovation, proactiveness and risk-taking capabilities to support the upper hand (Imran et al., 2017). Besides, EO practices for assembling firms are critical to encourage the usage of TQM for upgrades and increment the assembling efficiency and upper hand. Along these lines, for the better comprehension of export execution producing SMEs should construct a connection among EO and TQM. In like manner, EO and TQM are the elusive assets and abilities for firms, which can prompt high firm execution.

\section{$2.1 \quad$ EO and SME export execution}

EO is characterized as the company's level procedures, practices and dynamic styles of innovative firms (Lumpkin and Dess, 1996). Shan et al. (2016) expressed that EO is a key asset that alive business enterprise practices of the organizations. Numerous investigations suggested that EO is a significant apparatus to accomplish upper hand and which can improve the company's gainfulness (Zahra and Covin, 1995). The significance of EO for the endurance of SME export execution was recognized by numerous creators. Numerous examinations accepted that organizations with more grounded EO accomplish higher export execution. Hypothetically, EO catches the item and market advancement that expect the market hazard and found the new open doors for business achievement (De Clercq and Zhou, 2014). In this way, EO can be viewed as the methodology making the procedure that worry the "techniques, practices and dynamic styles and goals and activities of key players working in a powerful generative process"(Lumpkin, 1996). It has been clarified that EO is an administrative conduct which can permit the organizations to surpass the opposition by being congenial to advancements, broadmindedness to hazard and profoundly proactive to showcase openings.

Besides, after an extensive writing survey, the present examination reasons that EO has been operationalized into three measurements, for example, innovation, risk taking and proactiveness. In this manner, EO is basic for assembling small and medium enterprise that if small enterprises have the power on innovation, risk taking and proactive-ness, they will get a maintainable upper hand which prompts higher export execution. This announcement prompts the accompanying hypothesis: 
H1: Entrepreneurial orientation (EO) has direct influence on SME export execution.

\subsection{Total quality management and SME export execution}

Total Quality Management (TQM) is a way of thinking and most huge firms use it by and by (Yusof and Deborah, 2000). In regard of SMEs, the dread of losing the agreement with huge firms brings quality into their framework. TQM has been broadly embraced by SMEs in various nations to process and deal with the association through quality, improvement in profitability, addressing client needs and giving a serious margin. The past works identified with the TQM with regards to SMEs are developing (Abdullah and Abidin, 2012). Moreover, the huge majority of the writing examined the TQM relationship with firm execution in nearby market setting (Corredor and Goñi, 2011).

Furthermore, the past investigations announced that TQM had been decidedly identified with quality execution and operational excellence (Ng and Jee, 2012); advancement execution (Yusr, 2016); upper hand (Munizu, 2013); authoritative learning and money related excellence. In another point of view, Dess et al. (2015) expressed that the massive portion of the scientists found a high effect of TQM on firm execution in the assembling business.

In this way, the present examination accepts that TQM can be the persuasive supporter in assembling SME export execution in Nigeria. In this manner, the following hypothesis is proposed:

H2: Total quality management (TQM) directly influences on SME export execution.

\subsection{Entrepreneurial orientation and total quality management}

The concept of EO was observationally bolstered by numerous investigations with SME export execution and TQM was discovered a contributory job in SME export execution. Incredibly, constrained examinations researched the joined impact of entrepreneurial orientation and TQM with SME export execution. As indicated by Jafar et al. (2016); Sahoo and Yadav (2017) expressed that EO and TQM are the most significant systems and practices to reasonable upper hand, which prompts high export execution. Besides, it has been discovered that a positive connection among EO and TQM in Dubai police office.

In another examination, the analyst found the positive impact of EO with TQM in assembling SMEs in India setting. Along these lines, past examinations make some inspiration for researching the connection among EO and TQM in various setting, for example, in assembling SME export execution in Nigeria. Henceforth, the following hypothesis proposed:

H3: EO positively influences on TQM in manufacturing SMEs of Nigeria.

\section{$2.4 \quad$ Mediating role of TQM between EO and SME export execution}

The past examinations found the positive connection among EO and SME export execution in an alternate setting (Hernandez-Perlines, 2018; Ribau et al., 2017; Thanos et al., 2016). Then again, a portion of the examinations discovered either no or blend connection among EO and SME export execution (Feder, 2015; Felzensztein et al., 2015; Frishammar and Andersson, 2009). In any case, there is a variety in past investigations' discoveries. Consequently, barely any scientists have recommended that the connection among EO and SME export execution might be mind boggling. Supporting this contention, a few interior and outside elements were found between the EO and SME export execution, for example, showcasing capacity, worldwide business systems, hierarchical assets (monetary, social, instructive) unique ability (Monteiro et al., 2017).

Al-Dhaafri et al. (2016) led an examination in UAE and found the incomplete intervention of TQM among EO and Dubai police office execution One more examination led in India found the job of TQM among EO and assembling SMEs execution (Sahoo and Yadav, 2017). In view of these investigations, the present examination accepts that TQM will assume the interceding job among EO and assembling SME export execution with regards to Nigerian. Thusly, the following hypothesis proposed:

H4: Total quality management (TQM) mediates the relationship between EO and SME export execution.

\section{RESEARCH METHODOLOGY}

\subsection{Population, Sample Size, and Respondent}

This investigation was directed with regards to assembling SMEs of Nigeria. Enlisted organizations in Nigerian exporter indexes were taken as the examination populace. We have remembered organizations for this examination test outline which were meeting essential criteria, for example, meeting the meaning of SMEs and include in assembling and export activities. The criteria were utilized by Ibeh (2004) and Okpara and Kabongo (2009) in various nations' specific circumstance. As per prescribed criteria, we have recognized $6994 \mathrm{ex}$-doormen from top eight assembling export orientated sub-areas, for example, materials (2072), careful (1100), sports merchandise industry (1000), calfskin industry (905), packaging (448), cutlery (218), auto-versatile parts (332), pharmaceutical (600), an industry (169) and furniture industry (150). 
The investigation utilized the Krejcie and Morgan (1970) table to decide the example size. By alluding the Krejcie and Morgan (1970) example size table, 300 sixty-four (364) SMEs were chosen as an example size for the investigation. In addition, Beh and Shafique (2016) expressed that assembling SMEs of Nigerian reaction rate was 46\%. The example size of the examination was expanded by $54 \%$ for most extreme reaction rate and we have attempted to control the non-reaction blunder (Salkind, 2012; Saunders et al., 2009). In addition, as indicated by Sekaran and Bougie (2016) for greatest reaction rate that analyst should make re-minder calls and send update messages must be performed and these methods were embraced for acceptable reaction in the present investigation. Besides, we have embraced the stratified inspecting system. Right now, the quantity of inspecting units drawn from every stratum was proportionate to the populace size of the stratum (Eriksson and Kovalainen, 2015).

The investigation test was partitioned into ten (10) strata, for example, materials/clothing (167), careful (88), sports merchandise (80), calfskin/footwear (73), pharmaceutical (48), packaging (36), car parts (28), cutlery (18), electrical products (14) and Furniture (12). In addition, inside strata we have utilized the basic arbitrary examining strategy to choose the respondent from each gathering referenced before and appropriated the survey through the drop and pick technique. The firm-level was taken as a unit of investigation and taken the reaction from firm proprietors/export chiefs; a few examinations utilized this method (Calantone et al., 2004; Cavusgil and Zou, 1994). An aggregate of 572 polls conveyed to assembling SMEs, just 364 firms took an interest in the study with a reaction pace of $64.54 \%$. This reaction was adequate and comparable as past investigations (Beh and Shafique, 2016; Hassan et al., 2017; Hussain et al., 2015).

\subsection{Measures of variables}

Measures of the variable were adapted from past studies. The total quality management in this study contains five dimensions, where the leadership, strategy, people, resources, and process contained 6, 6, 6, 5 and 7 respectively.

Then, entrepreneurial orientation was adjusted from the Boso et al. (2012) study, which comprises three measurements, for example, innovation (6 items), risk-taking (4 items) and proactiveness (3 items). Also, we have embraced the adjusted form of Zou et al. (1994) export execution (EXPERF) scale with 9 things. A seven-point Likert scale was utilized to guarantee the high factual inconstancy among reactions, which extend from 1(Strongly dissent), 2 (Disagree), 3 (Somewhat disagree), 4 (Neutral), 5 (Somewhat concur), 6 (Agree), 7 (Strongly concur) (Choi and Eboch, 1998). The subtleties of the build measurements with things can be found in Table 1 .

Table 1: The scale of SME export execution and total quality management

Dimensions Total Quality Management

\begin{tabular}{l|l} 
leadership & managers of companies view cost as the most important compared to the quality of the product
\end{tabular} Managers of the companies present themselves as role models for the employees

Managers of our company do not want to give authority to employees for them to take decisions about their jobs

Managers of our company continuously acquire and update their knowledge that is valuable for the organization.

Managers of our company encourage and participate in continuous improvement initiatives.

\begin{tabular}{l|l}
\hline Strategy & In companies, the views of customers (the people/companies who buy or want to buy your company's
\end{tabular}
products) are considered important while designing new products.

In companies the views of suppliers are considered while shaping the company's objectives.

In companies, the execution of competitors and best-in-class companies is assessed and analyzed.

In companies, systematic measurement of losses (such as production losses, the losses due to rejection of finished products, etc.) is carried out.

In our company, information systems are in place to capture information about customers and markets.

\begin{tabular}{l|l} 
People & In our company, formal processes are used regularly (attitude surveys, employees' briefing, etc.) to find
\end{tabular} out employees' opinions and views.

In our company, specific quality training is offered to employees.

In our company, employees are encouraged to update their knowledge and skills.

In our company, teamwork is a common practice within the organization.

In our company, employees have easy access to the relevant information.

In our company, encourage the employee's opinions, suggestions about any of the activities of the organization. 


\begin{tabular}{|c|c|}
\hline \multirow[t]{11}{*}{ Process } & In our company, suppliers are encouraged to develop long-term partnerships with the organization. \\
\hline & $\begin{array}{l}\text { In our company does not give preference to quality over cost while making purchase agreements with } \\
\text { suppliers }\end{array}$ \\
\hline & In our company, execution of the suppliers is evaluated periodically. \\
\hline & In our company, updated information and resources are provided to all employees to perform their jobs. \\
\hline & $\begin{array}{l}\text { In our company tries to reduce the harmful effect of its activities on the environment. (Partnership and } \\
\text { resources) }\end{array}$ \\
\hline & In our company, proper procedures are established to perform different jobs. \\
\hline & $\begin{array}{l}\text { In our company, employees are aware of the parameters (temperature, pressure, etc.) } \\
\text { of different processes, which are needed to In our company, execution of production } \\
\text { processes is monitored. }\end{array}$ \\
\hline & In our company, development and innovation of production processes are emphasized. \\
\hline & $\begin{array}{l}\text { In our company, the research and development (R\&D) department is continuously working on the } \\
\text { development and improve- }\end{array}$ \\
\hline & $\begin{array}{l}\text { In our company, production processes are capable of producing products according to design } \\
\text { specifications. }\end{array}$ \\
\hline & In our company, proper systems are in place to deal with customer complaints \\
\hline Dimension & Entrepreneurial Orientation \\
\hline \multirow[t]{6}{*}{ Innovation } & $\begin{array}{l}\text { Our company has produced more new products for our export markets than our key export market } \\
\text { competitors during the past five years. }\end{array}$ \\
\hline & $\begin{array}{l}\text { On average, each year we introduce more new products in our export markets than our key export market } \\
\text { competitors. }\end{array}$ \\
\hline & $\begin{array}{l}\text { Industry experts would say that we are more innovative when it comes to } \\
\text { introducing new products in our export markets. }\end{array}$ \\
\hline & $\begin{array}{l}\text { Relative to our main export competitors, the products, we offer in our export } \\
\text { market(s) are Revolutionary. }\end{array}$ \\
\hline & Relative to our main export competitors, the products, we offer in our export market(s) are Inventive \\
\hline & Relative to our main export competitors, the products, we offer in our export market(s) are creative \\
\hline \multirow[t]{4}{*}{ Risk Taking } & Top export manager of our company, in general, tend to invest in high-risk export projects. \\
\hline & This company shows a great deal of tolerance for high risk export projects. \\
\hline & Our export strategy is characterized by a strong tendency to take risks. \\
\hline & Taking risk is part of our export business strategy. \\
\hline \multirow[t]{3}{*}{ Proactiveness } & Companies seeks to exploit anticipated changes in our export market ahead of our competitors. \\
\hline & Companies acts opportunistically to shape the export environment in which we operate. \\
\hline & Companies consistently tries to position ourselves to meet emerging export market demands. \\
\hline Dimension & SME export execution \\
\hline \multirow[t]{2}{*}{ Financial } & Firm export has been very profitable and has generated a high volume of sale \\
\hline & $\begin{array}{lr}\text { Firm export } & \text { has. } \\
\text { achieved } & \text { rapid } \\
\text { growth } & \end{array}$ \\
\hline
\end{tabular}


Strategic

Satisfaction
Firm export has improved our global competitiveness.

Firm export has strengthened our strategic position.

Firm export has significantly increased our global market share.

The export execution of firm has been satisfactory and has been successful.

Firm export has fully met our expectation.

\section{DATA ANALYSIS AND RESULTS}

Smart PLS Statistical Analysis Software has been utilized for basic condition displaying (SEM) appraisal. The present examination utilized the second-request intelligent developmental progressive model, type II with the two-organize approach (Becker et al., 2012). In the present investigation, TQM and EO were taken as a higher request developmental build as framed by first-request intelligent develops, for example, Leadership, Strategy, People, Process, Resources, Innovation, Risk Taking, Proactiveness. The endogenous variable (SME export execution of the examination was treated as first request intelligent develop).

\subsection{Measurement model approval}

In light of PLS (SEM), the evaluation of estimation model has been dissected appropriately by utilizing Smart-PLS 3.2.7. To close the estimation model discriminant legitimacy, unwavering quality and focalized legitimacy of the estimation of builds were watched and distinctly analyzed. The individual things unwavering quality was analyzed through their stacking and all things were accounted for more than 0.7 stacking. Further, develops unwavering quality was inspected through Cronbach alpha, composite dependability (CR), and normal fluctuation removed (AVE). Table 2 shows all aftereffects of CR, AVE and Cronbach alpha, their qualities are higher than limit esteems, for example, Cronbach alpha (.07), CR (0.7) and AVE (0.5) (Hair et al., 2014).

Table 2: Finding of the measurement model (First Order, Reflective)

\begin{tabular}{|l|l|l|l|}
\hline Constructs & Cronbach's Alpha & Composite Reliability (CR) & Variance Extracted (AVE) \\
\hline Leadership (LDR) & 0.83 & 0.88 & 0.53 \\
\hline People (PPL) & 0.83 & 0.87 & 0.51 \\
\hline Process (PRS) & 0.86 & 0.90 & 0.56 \\
\hline Resources (RES) & 0.77 & 0.84 & 0.52 \\
\hline Strategy (STR & 0.83 & 0.87 & 0.53 \\
\hline Innovation (INO) & 0.82 & 0.87 & 0.51 \\
\hline Risk Taking (RSK) & 0.9 & 0.88 & 0.63 \\
\hline Proactiveness (PRO) & 0.89 & 0.93 & 0.81 \\
\hline Export Execution (EP) & 0.93 & 0.94 & 0.61 \\
\hline
\end{tabular}

In addition, discriminant legitimacy was examined to decide the model outside consistency, in view of the Fornell-Larcker Criterion, as indicated by Fornell and Larcker (1981) that AVE of the inert variable ought to be higher than the squared relationships between the inactive factors. In this manner affirming the discriminant legitimacy and the outcome can be found in the Table 3 . 
Table 3: Fornell-Larcker Criterion

\begin{tabular}{|l|l|l|l|l|l|l|l|l|l|}
\hline & EP & INO & LDR & PPL & PRO & PRS & RES & RSK & STR \\
\hline EP & 0.79 & & & & & & & & \\
\hline INO & 0.60 & 0.72 & & & & & & & \\
\hline LDR & 0.49 & 0.39 & 0.73 & & & & & & \\
\hline PPL & 0.33 & 0.25 & 0.43 & 0.72 & & & & & \\
\hline PRO & 0.42 & 0.3 & 0.17 & 0.15 & 0.10 & & & & \\
\hline PRS & 0.39 & 0.19 & 0.43 & 0.55 & 0.26 & 0.75 & & & \\
\hline RES & 0.12 & 0.23 & 0.26 & 0.19 & 0.16 & 0.2 & 0.72 & & \\
\hline RSK & 0.60 & 0.65 & 0.55 & 0.23 & 0.22 & 0.26 & 0.12 & 0.80 & \\
\hline STR & 0.21 & 0.24 & 0.43 & 0.7 & 0.09 & 0.47 & 0.34 & 0.18 & 0.73 \\
\hline
\end{tabular}

Note: $\mathrm{EP}=$ export execution; INO = innovation; $\mathrm{LDR}=$ leadership; $\mathrm{PPL}=$ People; $\mathrm{PRO}=$ proactiveness; $\mathrm{PRS}=$ process; RES = Resources; RSK = risk taking; STR = strategy

\subsection{Measurement model for formative constructs}

The developmental measurement model was assessed through multicollinearity among things and investigation of their loads (Hair Jr et al., 2016). Greatest change swelling factor (VIF) esteem for every developmental pointer was registered and watched not as much as edge esteem 5 (Hair et al., 2014). Also, we have checked the centrality of loads with a resampling method (bootstrapping with 5000 resamples) and watched the nearness of a few non-critical developmental markers. Further, the specialists chose to keep these things, since when a marker's weight isn't critical, however the comparing thing stacking is moderately high (i.e., $\geq 0.50$ ), or factually noteworthy, the pointer ought to by and large be held (Hair Jr et al., 2016). The outcomes can be found in the Table 4.

Table 4: Findings of Measurement Model for Formative constructs

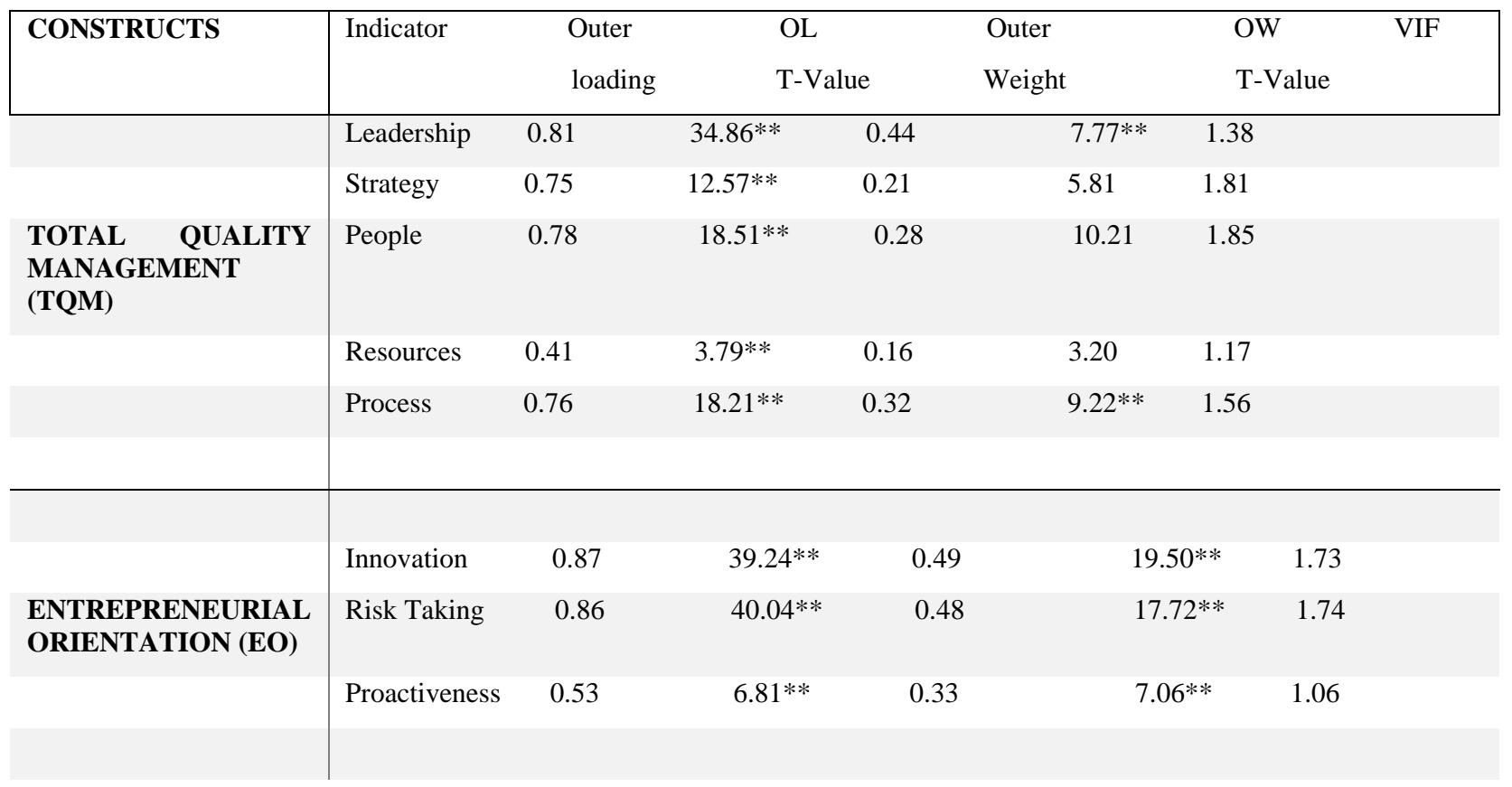

Note: $\mathrm{OL}=$ outer loading, $\mathrm{OW}=$ outer wrights, $* * \mathrm{p}<.01, * \mathrm{p}<.05, \mathrm{~ns}=$ not significant

\subsection{Structural Model Assessment}

After the evaluation of estimation model, the auxiliary model was surveyed to reach the determination. The basic model was assessed through way coefficient, the coefficient of assurance (R2) and impact size (F).

In way coefficient, appraisal assessed the immediate and aberrant connection between develops to acknowledge and dismiss the investigation proposed speculation. Be that as it may, for the immediate relationship, appraisal was performed (with 5000 sub-examining for 364 reactions) to decide the beta-qualities and t-values. Be that as it may, in the present 
investigation, three (03) direct connections were dissected and were upheld by three-direct connection transport theories. Table 5 shows all the immediate relationship results. The theory was acknowledged dependent on t-esteem watched more prominent than the edge estimation of 1.97.

Table 5: Findings of structural model (Direct effect results)

\begin{tabular}{|l|l|l|l|l|l|}
\hline & Beta & $\begin{array}{l}\text { Standard } \\
\text { Deviation }\end{array}$ & T Values & P Values & Decision \\
\hline H1: EO -> SME EP & 0.72 & 0.04 & $24.75^{* *}$ & 0.00 & Supported \\
\hline H2: TQM -> SME EP & 0.22 & 0.05 & $5.02 * *$ & 0.00 & Supported \\
\hline H3: EO -> TQM & 0.45 & 0.05 & $8.84 * *$ & 0.00 & Supported \\
\hline
\end{tabular}

Note: $* * \mathrm{p}<0.1, * \mathrm{p}<0.05, \mathrm{~ns}=$ not significant $(\mathrm{p}>.05)$ (Two Tail)

Hair et al. (2014) expressed that PLS (SEM) bootstrapping system for intercession examination is viewed as suitable. In this way, this investigation has analyzed the interceding job of EMO by utilizing the bootstrapping system at 5000 subtesting to decide the t-esteem. Be that as it may, Table 6 shows the consequences of intercession job of export showcase direction between complete quality administration and SME export execution.

Table 6: Findings of structural model (Indirect effect results)

\begin{tabular}{|l|l|l|l|l|l|l|l|}
\hline Hypothesis & Beta & SD & T-Value & P-Value & $2.5 \%$ & $98 \%$ & Results \\
\hline H4: TQM -> EO-> SME EP & 0.09 & 0.03 & $4.61^{* *}$ & 0.00 & 0.07 & 0.14 & Mediation \\
\hline
\end{tabular}

Note: $* * \mathrm{p}<0.1, * \mathrm{p}<0.05, \mathrm{~ns}=$ not significant $(\mathrm{p}>.05)($ Two Tail $)$

When decided the essentialness of the intervention impacts, the analysts can decide the sorts of intercession. The present investigation utilized the new proposed criteria of Hair Jr et al. (2016) to recognize the intercession type. As per this model utilized in the Fig. 2, we have decided the intercession type, and found the correlative intervention among EO and SME export execution.

\section{DISCUSSION AND CONCLUSION}

The consequences of the present examination have indicated that Entrepreneurial Orientation (EO) and Total Quality Management (TQM) clarified 53\% fluctuation of the SME export execution in the assembling segment. The present investigation has discovered a positive immediate and backhanded connection among EO and SME EXPORT EXECUTION. The critical consequences of EO with SME export execution are predictable with past investigations (Hernandez-Perlines, 2018). Be that as it may, as per the present examination, EO is discovered an important and contributory asset for SME export execution in the assembling division of Nigeria. Besides, the present examination has discovered a positive and direct connection among TQM and SME export execution in furniture industry of Nigeria and is predictable with the past investigations (Imran et al., 2018), moreover, the present investigation has uncovered the intervening job of TQM among EO and SME export execution These outcomes are steady with Al-Dhaafri et al. (2016); Sahoo and Yadav (2017), further, they contended that TQM rehearses are centered around productive procedure the board parts of the association, which prompts higher firm execution. Thusly, the present investigation results have uncovered that TQM is a contributory variable in SME sends out setting of Nigeria.

This examination adds to writing and helping the organizations that see how the procedure of EO right now creates better export execution through Total Quality Management. The present investigation results permit organizations that modify their endeavors to adjust EO and TQM with export execution results. In any case, the discoveries of the present investigation have proposed to Government of Nigeria and policymakers ought to consider assets and abilities, for example, both EO and TQM, which are extremely valuable for the accomplishment of SMEs in the global market. Also, in view of the discoveries of this examination it has been exactly settled that TQM assumes the fundamental job among EO and SME export execution with regards to Nigeria. Along these lines, SME proprietors/directors need to recognize the significance of TQM in improving firm export execution. Be that as it may, it is additionally critical to give full focus on EO, which would be gainful for TQM usage, and thusly, TQM will better act in the assembling SMEs, which will prompt higher SME export execution.

Future suggestions: current examination's system could be analyzed in various nation setting and various enterprises, for example, administrations industry, to sum up the outcomes. Besides, this is a cross-sectional examination, and we ought to approve this investigation in longitudinal approach. At last, different arbiters can likewise be explored between EOSME export execution connections. 


\section{REFERENCES}

- Abdin, J. (2017). SMEs and our development goals. The Daily Start. Retrieved from http://www.thedailystar.net/education-employment/smes-and-our-development-goals-1366591

- Ahmad, M., Zakuan, N., Ahmad, J., \& Takala, J. (2015). Meta-analysis of the TQM impact on business execution amongst regions and countries. International Journal of Industrial and Systems Engineering, 20(2), 155-164.

- Al-Dhaafri, H. S., Al-Swidi, A. K., \& Yusoff, R. Z. B. (2016). The mediating role of total quality man- agement between the entrepreneurial orientation and the organizational execution. The TQM Journal, 28(1), 89-111.

- Becker, J.-M., Klein, K., \& Wetzels, M. (2012). Hierarchical latent variable models in PLS-SEM: guide- lines for using reflective-formative type models. Long Range Planning, 45(5), 359-394.

- Beh, L.-S., \& Shafique, I. (2016). Does leadership matter in innovation and new business venturing? testing the mediating effect of absorptive capacity. International Journal of Innovation, Management and Technology, 7(5), 206.

- Bianchi, C., Glavas, C., \& Mathews, S. (2017). SME international execution in Latin America: The role of entrepreneurial and technological capabilities. Journal of Small Business and Enterprise De-velopment, 24(1), 176-195.

- Boso, N., Cadogan, J. W., \& Story, V. M. (2012). Complementary effect of entrepreneurial and market orientations on export new product success under differing levels of competitive intensity and financial capital. International Business Review, 21(4), 667-681.

- Calantone, R. J., Tamer Cavusgil, S., Schmidt, J. B., \& Shin, G. C. (2004). Internationalization and the dynamics of product adaptation - An empirical investigation. Journal of Product Innovation Manage- ment, 21(3), 185-198.

- Cavusgil, S. T., \& Zou, S. (1994). Marketing strategy-execution relationship: an investigation of the empirical link in export market ventures. The Journal of Marketing, 58(1), 1-21.

- Chen, Sousa, C., \& He, X. (2016). The determinants of export execution: a review of the literature 2006-2014. International Marketing Review, 33(5), 626-670.

- Choi, T. Y., \& Eboch, K. (1998). The TQM paradox: relations among TQM practices, plant execution, and customer satisfaction. Journal of Operations management, 17(1), 59-75.

- Abdullah, A., \& Abidin, Z. Z. (2012). Total Quality Management Enablers for SMEs: A Study of Malaysian Companies. GSTF Business Review (GBR), 2(2), 71.

- Corredor, P., \& Goñi, S. (2011). TQM and execution: Is the relationship so obvious? Journal of Business Research, 64(8), 830-838.

- De Clercq, D., \& Zhou, L. (2014). Entrepreneurial strategic posture and execution in foreign markets: the critical role of international learning effort. Journal of international Marketing, 22(2), 47-67.

- Demirbag, M., Lenny Koh, S., Tatoglu, E., \& Zaim, S. (2006). TQM and market orientation's impact on SMEs' execution. Industrial Management \& Data Systems, 106(8), 1206-1228.

- Eriksson, P., \& Kovalainen, A. (2015). Qualitative Methods in Business Research: A Practical Guide to Social Research, Sage.

- Fatemah, A., \& Qayyum, A. (2018). Modeling the Impact of Exports on the Economic Growth of Paki- stan.

- Feder, E.-S. (2015). International market, entrepreneurial and learning orientations as drivers of firm execution. Studia Universitatis Babes-Bolyai, 60(1), 3.

- Felzensztein, C., Ciravegna, L., Robson, P., \& Amorós, J. E. (2015). Networks, entrepreneurial orientation, and internationalization scope: evidence from Chilean small and medium enterprises. Journal of Small Business Management, 53(S1), 145-160.

- Fornell, C., \& Larcker, D. F. (1981). Evaluating structural equation models with unobservable variables and measurement error. Journal of Marketing research, 18(1), 39-50.

- Frishammar, J., \& Andersson, S. (2009). The overestimated role of strategic orientations for international execution in smaller firms. Journal of International Entrepreneurship, 7(1), 57-77.

- Gupta, V. K., \& Batra, S. (2015). Entrepreneurial orientation and firm execution in Indian SMEs: Universal and contingency perspectives. International Small Business Journal, 0266242615577708.

- Hair, J. F., Hult, G. T. M., Ringle, C. M., \& Sarstedt, M. (2014). A Primer on Partial Least Squares Structural Equation Modeling (PLS-SEM). Los Angeles, CA: SAGE.

- Hair Jr, J. F., Hult, G. T. M., Ringle, C., \& Sarstedt, M. (2016). A primer on partial least squares structural equation modeling (PLS-SEM) (2nd ed.). Thousand Oaks, CA: SAGE.

- Hernandez-Perlines, F. (2018). Moderating effect of absorptive capacity on the entrepreneurial orientation of international execution of family businesses. Journal of Family Business Management. 